УДК 372.8 - Преподавание отдельных учебных предметов

DOI https://doi.org/10.24919/2308-4863/41-3-26

Ayshan RASULOVA, orcid.org/0000-0003-1643-8579

Doctoral Student at the Department of Pedagogy and Methodology of Education

Ganja State University

(Ganja, Azerbaijan) afaqqasimova@bk.ru

\title{
PSYCHOLOGICAL BASES OF FORMATION OF LIFE SKILLS OF TEENAGERS IN FINE ART CLASSES
}

\begin{abstract}
The purpose of the article is to analyze the psychological basis of the formation of life skills in high school students in fine arts classes.

Methodology and methods used. The article examines the content of a psychologically correct approach to the inculcation of life skills in senior students in the process of teaching topics in textbooks prepared on the basis of program materials for grades V-IX. The article also analyzes the place, role and importance of psychological features such as emotion, perception, memory, attention, imagination and thinking, which play a role in the development of life skills of high school students.

The main scientific innovation. The article scientifically, theoretically and practically substantiates the importance of the organization of fine arts classes in accordance with the requirements of modern times and their impact on the psychological development of students. When informing high school students about the place of fine arts in life and society, they should involve them in active communication with art and develop their aesthetic attitude to art. At this time, students acquire rich life skills. The acquisition of life skills by students in the fine arts classes not only forms their aesthetic and artistic tastes, but also ensures their personality-oriented development. For this purpose, first of all, there is a need to determine the psychological basis of the formation of life skills of high school students in fine arts classes. All this is analyzed in the article. The above can be considered as scientific innovations of the article.

The results of the study.

- It has been determined how important it is to follow the new teaching principles in the process of teaching fine arts.

- There is a need to correctly define the psychological basis of the formation of life skills of adolescent students in fine arts classes. Because it is important to properly identify the psychological basis of this work in order to acquaint senior students with works of fine arts, to reveal, develop and form life skills in the field of teaching and analyzing these works.

- Under the guidance of a teacher, the creativity of adolescent students acquires new features. At the same time, the importance of the developmental, activating training methods applied increases.

- The educator should take into account the interests of Teenagers and choose topics that allow each student to have a positive emotional response to the task, and as a result, the child can both demonstrate and develop creativity.

Key words: fine arts, life skills, psychological approaches, psychological features, motives for action
\end{abstract}

Айшан РАСУЛОВА,
orcid.org/0000-0003-1643-8579
докторант кафедри педагогіки і методики виховання
Гянджінського державного університету
(Гянджа, Азербайджан) ағаqqаsimova@bk.ru

\section{ПСИХОЛОГІЧНІ ОСНОВИ ФОРМУВАННЯ ЖИТТЕВИХ НАВИЧОК ПІДЛІТКІВ НА КЛАСАХ ЗОБРАЖЕННЯ}

\footnotetext{
Метою статті є аналіз психологічних основ формування життєвих навичок у стариокласників на уроках образотворчого мистеитва.

Використовувана методологія і методи. У статті розглядається зміст психологічно правильного підходу до прищеплювання життєвих навичок старшокласникам в процесі викладання тем в підручниках, підготовлених на основі програмних матеріалів для V-IX класів. У статті також аналізуються місие, роль $i$ значення таких психологічних особливостей, як емоиії, сприйняття, пам'ять, увагу, уяву і мислення, які відіграють певну роль у розвитку життєвих навичок старшокласників.

Головний науковий нововведення. У статті науково, теоретично і практично обтрунтовується важливість організації занять образотворчим мистеитвом в відповідно до вимог сучасності та їх вплив на психологічний розвиток учнів. Інформуючи старшокласників про місие образотворчого мистеитва в житті і суспільстві, вони повинні залучати їх до активне спілкування з мистецтвом і розвивати у них естетичне ставлення до мистеитвва. В ией час студенти набувають багаті життєві навички. Придбання студентами життєвих навичок на заняттях образотворчим мистецтвом не тільки формує їхні естетичні та художні смаки, а й забезпечує їх осо-
} 
бистісно-орієнтований розвиток. Для изього, перш за все, необхідно визначити психологічні основи формування життєвих навичок старшокласників на заняттях образотворчим мистецтвом. Все це аналізується в статті. Все вищесказане можна розглядати як наукові нововведення статті.

\section{Результати дослідження.}

- Було визначено, наскільки важливо дотримуватися нових принципів викладання в процесі викладання образотворчого мистецтва.

- Необхідно правильно визначити психологічні основи формування життєвих навичок учнів-підлітків на заняттях образотворчим мистецтвом. Тому щчо важливо правильно визначити психологічну основу цієєї роботи, щзоб познайомити старшокласників з творами образотворчого мистеитва, виявити, розвинути і сформувати життеві навички в галузі викладання і аналізу циих творів.

- Під керівництвом викладача творчість учнів-підлітків набуває нових рис. У той же час зростає важливість застосовуваних розвиваючих, які активізують методів навчання.

- Педагог повинен враховувати інтереси підлітків і вибирати теми, які дозволяють кожному учневі позитивно емоційно відреагувати на завдання, $і$ в результаті дитина може як проявити, так $i$ розвинути творчі здібності.

Ключові слова: образотворче мистецтво, життєві навички, психологічні підходи, психологічні особливості, мотиви діï.

Introduction (problem statement). The directives on educational reforms in Azerbaijan require that the younger generation be taught a number of life skills in order to teach them to protect national and spiritual and universal values, to love the Motherland and to appreciate innovations. In accordance with these requirements, urgent tasks are set for subject teachers and all pedagogical staff working in secondary schools to instill in Teenagers the most necessary life skills. In order to successfully solve these tasks, subject teachers have to teach teenagers to protect and develop national-moral and universal values, to equip them with purposeful, planned and organized skills in order to equip them with the most necessary knowledge and skills, there are serious tasks for teachers of fine arts, as well as subject teachers working in secondary schools. Because when teachers of fine arts inform high school students about the places of fine arts in life and society, they actively communicate with art develop their aesthetic attitude to art. At this time, students acquire rich life skills. The acquisition of life skills by students in the fine arts classes not only forms their aesthetic and artistic tastes, but also ensures their personality-oriented development. For this purpose, first of all, there is a need to determine the psychological basis of the formation of life skills of high school students in fine arts classes.

The purpose of the article is to analyze the psychological basis of the formation of life skills in high school students in fine arts classes.

Methodology and methods used. The article examines the content of a psychologically correct approach to the inculcation of life skills in senior students in the process of teaching topics in textbooks prepared on the basis of program materials for grades V-IX. The article also analyzes the place, role and importance of psychological features such as emotion, perception, memory, attention, imagination and thinking, which play a role in the development of life skills of high school students.

In recent years, publications on the subject have provided students with detailed information about the essence, content, artistic features, and aesthetic value of works of fine arts taught in fine arts classes. The importance of their psychologically correct approach to the inner world of artistic images, to the deep perception of beauty, its easy perception and objective evaluation is emphasized.

According to the requirements of the Fine Arts curriculum, the learning process is based on predetermined outcomes. In this process, the teacher is the "facilitator" who coordinates, guides, and directs, and the students are the creative subjects who learn, research, apply, and present what they have learned. The subject of fine arts plays an important role in the development of students' knowledge and skills, logical, critical and creative thinking, being taught at the level of primary (I-IV grades) and general secondary (V-IX grades). There are many opportunities for students to develop conceptual knowledge and psychomotor skills. The teaching of fine arts is a purposeful process based on mutual understanding and communication between the trainer (teacher) and the learner (student). Although the main goal here is to teach learning (creation), sometimes "teachers" prefer to "teach" as they learn. In this case, the needs of students are not taken into account the learning process is organized regardless of their skills and desires, which in general has a negative impact on the quality of education. Such an approach to the teaching of the subject reduces students' interest in learning, creates self-doubt, deprives them of the desire to describe what they imagine, the ability to apply abstract ideas in real life, reduces the development of creative thinking in various fields (Curriculum on Fine Arts for I-IX Grades of Secondary Schools, 2013, p.46-47). 
M. Hamzayev in his book "Age and the basics of pedagogical psychology" shows that the learning activities of Teenagers differ from small schoolchildren in a number of features. First of all, not one teacher, but several teachers start to deal with them. Often, these teachers differ in their behavior, communication style, and teaching style. Different teachers have different requirements for a teenager. This forces teenagers to adapt to each new teacher individually. At the same time, during teenager, a distinctive attitude towards individual teachers begins to manifest itself. Teenagers love some teachers, are disgusted with some, and are indifferent to others (Hemzeyev, M., 2002, p. 51). Therefore, in fine arts classes, it is necessary to make students love to feel, comprehend and appreciate works of fine art. The author also notes that memory develops significantly during teenager. Logical memory begins to develop actively. Teenagers prefer to use logical as well as arbitrary memory. Due to this, the development of mechanical memory slows down. Teenagers are becoming more interested in ways to improve memory (Hemzeyev, M., 2002, p. 52).

One of the works published in recent years on the subject is a textbook by M. Akbarova entitled "Fine Arts and its teaching methods". The textbook consists of three parts and is based on the program in accordance with the new standards. The textbook consists of theoretical and practical parts. In the theoretical part takes place: History and types of fine arts; Pedagogical bases of fine arts training; Creative fine arts training in kindergarten. In the experimental part, examples and reviews on fine arts are given (Ekberova, M., 2012).

Analysis of the effects of fine arts and the emotional development of adolescents: There are topics in the curriculum developed for fine arts classes and in textbooks based on that curriculum that in order to bring students closer to those subjects, it is necessary to first adjust their memory, then their attention, and then their imagination and thinking skills. For example, in the fine arts textbook for 6th grade, "Man and Fine Arts", "Painting is the Basis of Fine Arts", "Reality and Fantasy in Painting", "Spectrum and Color Circle", "Color in Painting", "Types of Sculpture In order to involve students in the creative process during the teaching of "Materials and images in sculpture", "Natural forms in ancient columns", "Symbol of elegance and mercy", teachers refer to their skills and competencies to teach students to hear, comprehend, memorize these topics, they must be taught how to filter the imagination. In this regard, psychologists show that all the mental processes of man, his emotions, perception, memory, thinking and imagination are involved in the creative process. It is also a fact that the role of the imagination in the creative process is more pronounced. Imagination is of exceptional importance, especially in art. Every literary and artistic work has an idea. Unlike in scientific works, the artist-writer reflects this idea through concrete images, and the artist-painter reflects the aesthetic harmony of colors (Seyidov, S., Hemzeyev, M., Mustafayev, T., 2007, p. 342]. Therefore, in the process of teaching the listed topics, it is necessary to prepare students to be careful in this context. Because in order to feel and perceive examples of fine art, it is necessary to pay attention to it purposefully. It is especially useful for teachers to make efforts to develop the attention of students in grades VII-VIII. This is because the fact that students pay attention to examples of fine arts during teenager expands their interest in this field.

There are also peculiarities in the development of attention during teenager. During this period, there are frequent distractions. Major changes in the child's learning activities, changes in needs and interests, the student's attitude to different subjects, teachers, mental states, the abundance of new and colorful impressions, strong impressions associated with the onset of puberty, problems with adulthood, etc. can lead to the manifestation and development of attention, where emotional states manifest themselves (Hemzeyev, M., 2002 , p. 53). Such cases are more common in students of VII-VIII grades. Therefore, when organizing educational work with students of VII-VIII grades on fine arts, it is necessary to adapt the teaching of fine arts to students to the level of their imagination. A number of topics in the 7th grade fine arts textbooks, including "Monumental painting", "Legendary images in fine arts", "Human image in plot works", "Human image in sculpture", "The role of clothing in society" need special attention should be paid to the development of the imagination of teenagers in the teaching of topics.

Because during this period, important conditions are created for the development of their imagination. Because the development of restorative imagination during teenager focuses more on the perception of artistic images in students. In order to create legendary images, traditional human images, it is expedient to study students' attitudes towards romantic works, fantastic artistic speeds and interest in creating appropriate images and speeds. Because much progress is made in the development of the imagination during teenager. Restorative imagination reaches a high level of development. There is a tendency to create romantic, fantastic images. Adolescents' imaginations change with age. At the age of 14-15, imaginary images become more realistic and more critical. At 
the same time, at that time, teenagers could not completely get rid of romantic images (Hemzeyev, M., 2002 , p. 53). Because they try to analyze in their minds the same speed and images that they imagined during the transition to the eighth grade.

Adolescents are especially advanced in the development of thinking. Their thinking is fundamentally different from that of younger students. During this period, thinking is more generalized, deeper and more abstract. Typically, younger students mainly compare specific objects, prefer the expression of individual judgments, and are mainly based on general ideas and concepts of everyday life. Adolescents, on the other hand, learn scientific concepts and refer to them. It uses more general judgments, and their thinking becomes more abstract. Abstract thinking develops rapidly in adolescents (Hemzeyev, M., 2002, p. 54). Therefore, when studying examples of fine arts in VIII-IX grades, it is important to pay attention to the development of students' thinking. Because of in the process of developing thinking, it is possible to determine the motives of the student's personality. Many of the topics included in the VIII grade curriculum, including "False and Historical Genres in Fine Arts", "Francisco Goya: The Impact of Life Events on the Artist's Color World", "Impressionism: Poetry of Impressions", "Vincent Van Gogh: Color, Line, and It is important to take a purposeful approach to the development of students' thinking in the process of teaching topics such as "the emotional impact of forms". Because the development of thinking in this period, as we have noted, it is possible to correctly determine the motives of the student's personality and the main directions of activity on these motives.

Motives of a person determine the direction of his activity. The specific characteristics of the activity are determined by the purpose, not the motive. On the one hand, different goals are formed on the basis of the same motive. On the other hand, the same goal is associated with different motives in different people. This is the dialectical connection between motive and purpose. However, in all cases the psychological function of the motive is the same: it motivates a person to action and determines the direction of his activity. These two aspects (motivation and direction) are intertwined and appear as the main functions of the motive (Bayramov, A.A., Alizade, A.A., 2002, p. 146). Therefore, the correct identification of students' motives in fine arts classes is one of the main conditions. Suppose that during the discussion of paintings on the theme of "Holidays" it is necessary to determine the main motives of the activity. In this case, it is necessary for the fine arts teacher to provide students with local information about spring. Because the incentives to provide such information help to correctly identify the main directions of students' motivations. When working on paintings related to Nervous holiday in the program materials of VIII grades, the teacher's information in the following way can correctly determine the main directions of the motives of teenagers' activities. Provided that the subject information is presented to the classroom by the subject teachers as follows:

-Children, spring is the most beautiful season of the year. In the spring, our country is flooded with colorful paints; the fields are green, the rivers are flowing, the waters are purifying, the bare, gray trees in the forests are dressed in green. In spring, our people celebrate one of its holiest holidays, Nervous. To celebrate the holiday, the house is cleaned, people wear fresh, colorful clothes, festive tables are set in each house, and colorful eggs, various cookies, fruits, sweets, and delicious food are placed there. On the day of the holiday, everyone visits each other, the sick and the disabled are visited, a bonfire is lit, and everyone who jumps over it:

"May my weight and success take place, may God provide for me", he said, relieving his pain, and so on.

Such information not only educates students in the spirit of love for the people, the land, the Motherland, but also acquaints them with the national treasures and traditions of their people. At the same time, they are more interested in painting on the theme of nationalism (Sadiqov, F.B., 1994, p. 209). Such approaches encourage students to draw on the theme of Nervous. They draw such drawings on the basis of information provided by the teacher and under the influence of the teacher's analysis of the Nervous holiday. They try to express the moments, elements and details depicted in their paintings at the level of their imagination. At the same time, the symbols of Nervous holiday, the colorful colors and elements of spring come to life in their paintings. In this process, the spring symbols, elements, details, and lines that students pass through the filter of thinking are reflected in their paintings. Because in such a process of activity, that is, in such a high level of development of thinking, the motives of action begin to manifest themselves as creative motives. In this case, fine arts teachers should try to ensure that the symbols, elements, and lines of the Nervous Holiday described by the students correspond to the nature of the learning motives. In other words, the theme of Nervous holiday, the attitude of teenagers to the Nervous holiday of their country is motivated against the background of the formation of their moral qualities, along with the purification of their morals. Psychologists have proved that in some cases, students also show creative motives. At 
the same time, the nature of learning motives gradually changes, in which the characteristics of creativity begin to take center stage. In addition, it must be borne in mind that both cognitive and social motives can have a collectivist, narrow-minded, or even selfish orientation. This means that the fact that a student has a certain cognitive motive and social motive is not enough to characterize his personality, it is necessary to clarify the quality of motives in order to analyze the direction of personality (Abbasov, A.N., 2012, p. 148). Because the development and formation of learning motives of students of VIII-IX grades expands their interest and tendency to fine arts, and most importantly, provides them with dynamic assistance in revealing a number of life skills. Because of teachers who analyze on the subject of any descriptive dissemination are submitted by adapting this analysis to the nature of the training motifs. In such a presentation process, opportunities to reveal, develop and form more vital skills are expanding. When you say opportunities, it is necessary to talk about the natural capabilities of the upper class students. Because the natural capabilities of VIII-IX graders are increasing their sensitivity to their fine works of art. In tutorials based on program materials based on the IX classrooms, there are topics that the analysis of these issues arises specifically for the extraction of the natural resources of the art. For example, in the IX classroom "Omar Eldarov: Beauty and Harmony", "Cartoon and Charging: pictorial stories", during the teaching process, fine arts teachers should conduct purposeful observations to identify students with natural resources. In the process of observations, he must recommend that the works involved in the students are involved in the work. During the analysis, Omar Eldarov"s attitude to the work of "Beauty and Harmony" the study of students may lead to a more interesting lesson. In particular, the way students thinking about cartoon and charger genres can detect with their natural resources (Eldarov, O., 2021).
In psychology, the concept of "natural opportunities" includes psychophysiological properties along with anatomical-physiological features of the body, and commenting on these endings as the main. If the psychological nature said, first of all, in the initial stage of operating in the child, sometimes regularly indicates the sensitivity of self-determination, visual memory, music hearing sensitivity, etc. as the properties is understood. Such natural opportunities show themselves while in contact with a certain irritant, object, which is adequately adequate to them in one way or another. For example, in the perception of music, landscape etc. children with relevant natural opportunities and inclined to the activities of the activity are clearly manifested (Bayramov, A.A., Alizade, A.A., 2002, p. 426-427). So, in the process of attracting Omar Eldarov`s "Beauty and Harmony", all students in the classroom will not be able to make the beauty elements in the work, and will not be able to admit harmony features and will not be able to make detailed ideas. Only natural opportunities may be possible to identify these beauty lines and harmony elements of beauty by identifying students. In this case, it is possible to reveal vital skills in students related to these beauty features and harmony elements. Under the leadership of the teacher, the student's creativity gets newer features. At the same time, the importance of the developmental activating training methods is even greater. Teacher should take into account the student's interest and choose themes to choose a positive emotional attitude to the task given in every child, and eventually develop children's creativity (Ekberova, M., 2012, p.4-5).

All this is due to saying that there is a need to properly define the psychological basis for the formation of vital skills of teenagers in fine art classes. Because the improvement of high-ranking artists of the upper class students, to identify vital skills in teaching and analysis of these works, the correct identification of the psychological basis for the formulation of this work is important.

\section{BIBLIOGRAPHY}

1. Azərbaycan Respublikasının Ümumtəhsil Məktəblərinin I-IX Sinifləri Üçün Təsviri İncəsənət Fənni Üzrə Təhsil Proqramı (Kurikulumu). Azərbaycan Respublikası Təhsil Problemləri İnstitutu. Bakı, 2013, 122 s.

2. Abbasov, A.N. Müəllim hazırlığına yeni yanaşmalar. Baku: Mütərcim, 20212, 358 s.

3. Bayramov, A.A., Alizade, A.A. Psixologiya. Bakı: Çinar-Çap Neşriyayatı-Poliqrafiya Müessisesi, 2002,620 s.

4. Ekberova, M. Tesviri senet ve onun tedrisi metodikası (derslik). Bakı: Avanqard, 2012, $202 \mathrm{~s}$.

5. Eldarov, Ö. Gözəllik və Harmoniya. http: //www.e-derslik.edu.az/books/147/units/unit-1/page67.xhtml (last show 23. 07. 2021)

6. Hemzeyev, M. Yaş ve pedaqoji psixologiyanın esasları, Bakı: Adiloğlu, 2002, 528 s.

7. Sadıqov, F.B. Uşaqların bədii yaradıcılıq qabiliyyətlərinin formalaşdırılması işinin elmi-pedaqoji əsaslarə. Bakı: ADPU-nun mətbəəsi, 1994, 224 s.

8. Seyidov, S., Hemzeyev, M., Mustafayev, T. Psixologiya (Ali pedaqoji məktəblərin bakalavr pilləsi tələbələri üçün dərslik). Bak1: Nurlan, 2007? 650 s. 


\section{REFERENCES}

1. Azərbaycan Respublikasının Ümumtəhsil Məktəblərinin I-IX Sinifləri Üçün Təsviri İncəsənət Fənni Üzrə Təhsil Proqramı (Kurikulumu). (2013), [Curriculum on Fine Arts for I-IX Grades of Secondary Schools of the Republic of Azerbaijan. Institute of Educational Problems of the Republic of Azerbaijan. Baku], Azərbaycan Respublikası Təhsil Problemləri İnstitutu. Bak1, $122 \mathrm{~s}$.

2. Abbasov, A.N. (2012), Abbasov, A.N. [New Approaches to Teacher Training. Baku: Translator], Müəllim hazırlığına yeni yanaşmalar. Baku: Mütərcim, $358 \mathrm{~s}$.

3. Bayramov, A.A., Alizade, A.A. (2002), Bayramov A. A, Alizade A.A. [Psychology. Baku: Chinar-Printing PublishingPrinting Enterprise], Psixologiya. Bakı: Çinar-Çap Neşriyayatı-Poliqrafiya Müessisesi, $620 \mathrm{~s}$.

4. Ekberova, M. (2012), Ekberova, M. [Fine arts and its teaching methods (textbook). Baku: Vanguard], Tesviri senet ve onun tedrisi metodikası (derslik). Bak1: Avanqard, $202 \mathrm{~s}$.

5. Eldarov, Ö. Eldarov, O. [Beauty and Harmony], Gözəllik və Harmoniya. http: //www.e-derslik.edu.az/books/147/units/ unit-1/page67.xhtml

6. Hemzeyev, M. (2002), Hamzayev, M. (2002), [Basics of age and pedagogical psychology, Baku: Adiloglu], Yaş ve pedaqoji psixologiyanın esasları, Bakı: Adiloğlu, $528 \mathrm{~s}$.

7. Sadiqov, F.B. (1994), Sadigov, F.B. [On the Scientific and Pedagogical Basis of the Work on the Formation of Children`s Artistic Creativity. Baku: ASPU Printing House], Uşaqların bədii yaradıılıq qabiliyyətlərinin formalaşdırılması işinin elmipedaqoji əsaslarə. Bak1: ADPU-nun mətbəəsi, $224 \mathrm{~s}$.

8. Seyidov, S., Hemzeyev, M., Mustafayev, T. (2007), Seyidov, S., Hamzayev, M., Mustafayev, T. [Psychology (textbook for undergraduate students of higher pedagogical schools). Baku: Nurlan], Psixologiya (Ali pedaqoji məktəblərin bakalavr pilləsi tələbələri üçün dərslik). Bakı: Nurlan, $650 \mathrm{~s}$. 